\title{
PERSONNEL MANAGEMENT AND CORRUPT ACADEMIC PRACTICES IN UNIVERSITIES IN CROSS RIVER STATE, NIGERIA
}

\author{
Arop, Festus Obun \\ Department of Educational Administration and Planning, \\ University of Calabar, Calabar, Nigeria \\ aropfestusobun@yahoo.com \\ Ekpang, Martin Akan \\ Department of Educational Administration and Planning, \\ University of Calabar, Calabar, Nigeria \\ ekpang.martinsakan@gmail.com \\ Nwannunu, Blessing Iheoma \\ Department of Educational Administration and Planning, \\ University of Calabar, Calabar, Nigeria \\ blessme4sure@gmail.com

\section{Owan, Valentine Joseph} \\ Department of Educational Administration and Planning, \\ University of Calabar, Calabar, Nigeria \\ owanvalentine@gmail.com
}

\begin{abstract}
The study examined personnel management and corrupt academic practices in universities in Cross River State, Nigeria. In achieving this objective, two research questions and two null hypotheses were posed and formulated respectively, to guide the study. The study adopted a factorial research design, while the population of the study included all the academic staff and students from University of Calabar and Cross River University of Technology. A purposive sampling technique was employed to select 1200 students and 200 lecturers from both Universities, resulting in a sample of 1400 respondents. The instrument used for data collection
\end{abstract}


was a 25-item rating scale that was designed by the researcher to assess both students and lecturers respectively. The collected were analyzed using descriptive statistics, while the null hypotheses were tested at .05 alpha level, using multiple regression analysis. The results of the analysis revealed that; discipline and remuneration of lecturers influenced lecturers' corrupt academic practices in the universities, with remuneration having the most influence. The findings of the study also revealed that discipline and supervision of university students have a joint significant influence on university students' corrupt academic practices, with students' supervision having the most influence on corrupt academic practices. Based on these findings, it was recommended among other things that university lecturers should be properly remunerated through frequent payment of salaries, and other wages in order to ensure that they do not lack food and other resources to manage and take proper care of their families; students should be supervised properly during examinations and in other academic/ co-curricular activities of the universities.

Keywords: Personnel; Management; Personnel Management; Corruption; Academic Practices

\section{INTRODUCTION}

Education institutions are considered as creators of public goods through the production of human capital that is realized through knowledge enhancement and skill mastery. Human capital, in its turn, directly and indirectly, i.e. through social capital (networks, norms, trust), produces and strengthens social cohesion (Heyneman, 2003). The future of the Nigerian educational system depends largely on the extent to which academic activities are carried out in our schools.

The university system has failed to produce quality graduates who meet the demand of the society. As a result, there is a mismatch between what the university system supplies and what the society demands. A situation where many Nigerian graduates cannot compete favourably with those of the rest of the world is an indicator that there is something wrong with our university system specifically, and the educational system generally. The poor performance of graduates especially when they are employed, is a true reflection of the fact that they were not properly trained, or their behaviour were not properly modified. Those responsible for modifying learners' behaviour are the teachers who should inculcate good attitudes, values and skills to the learners. Sadly, abnormalities exist in the university system which as a consequence, results in poor performance of graduates. These abnormalities can be seen as 
corrupt practices, since they are a deviation from acceptable standards within the school system.

Corruption according to Brunnelle-Quraishi (2011) is derived from the Latin word "corruptus" which translates as "to break". Lawal and Tobi (2006:643), "corruption is any conscious attempt or deliberate diversion of resources from the satisfaction of the general interests to that of the selfish (personal or particular interest). Ojiade (2000) is more inclusive in his definition of corruption when he writes that corruption is any systematic vice perpetuated by individuals, society or a state in general, where not-too-good concepts for equality, social harmony and harmonious living e.g. favouritism, nepotism, tribalism, sectionalism, undue enrichment, amassing of wealth, abuse of office, power, position etc. become norms upon which the people and the state operate. In this paper, corruption is seen as any deliberate and malicious efforts made by a person or group of persons to go contrary to set rules within the environment that such a person or people find themselves.

The wide spread or prevalence of corruption in Nigeria means that there is hardly any sector of the Nigerian society that can be exempted as not being corrupt. Be this as it may, there are sectors in which the prevalence of corruption in them can terribly and disastrously destroy a state and her people and one sector where this is real is education. This position is taken because corruption in the education industry is terribly detrimental to the moral and general health of the Nigerian state (Nwaokugha \& Ezeugwu, 2017). Corruption affects three major aspects of education: access, equity and quality (Heyneman, 2009). Corruption in higher education is difficult to define. What is considered to be corrupt behaviour by some, may be considered acceptable or normal by others. For instance, insisting that a student's opinion mirror that of a professor is considered corrupt by some, but others consider that to be normal. According to Nwaokugha and Ezeugwu (2017), corruption in the education industry terribly creates infrastructural deficits that result in poor instructional delivery and making many people not to have access to education which in addition to being a fundamental human right, is a spring board for their empowerment and emancipation of infrastructural deficits. The inability of a people to have access to education systematically renders useless, the ability of the people to engineer national development as generations of citizens are left frustrated, disgruntled and disenchanted in addition to manifesting terrible immorality in the forms of militancy and insurgency.

Corrupt academic practices refer to the various activities that teachers and students engage in, that are not consistent with the prescribed pattern of behaviour expected, and that are inimical to the realization of set goals. Nwaokugha and Ezeugwu (2017) reported that classroom teachers are not left out in the orgy of corruption and corrupt practices in Nigeria's 
education industry, and a pattern of corruption that is unique to them is sale of grades, sexual harassment, absenteeism, fragrant abandonment of teaching and in its place, engineering and initiating a culture of private practices, whereby learners are forced to participate in such privately organized tutorials using school facilities. Where exorbitant charges and fees are paid and learners who refuse to be part of such private tutoring are frustrated in addition to being singled out for unmerited victimization. At the tertiary education level in Nigeria, corruption exists in more sophisticated forms at virtually all units of the tertiary education levels ranging from admissions office, bursary, personnel, works, students' affairs etc. In most Nigerian tertiary educational institutions, corruption harmonizes very well with ethnicity and under their joint covers, certain choice appointment and positions are reserved and made the exclusive rights of some members of certain ethnic nationalities, even when they do not have the requisite qualifications to enable them pick up and occupy such positions.

In Cross River State, there is a high rate of corrupt academic practices amongst lecturers and university students. Many students in an attempt to graduate with good classes of degrees, do not pay attention to their books, they resort to cheating during exams, copying from friends, bringing extraneous materials ("brain support" as many of them call it), bribing lecturers using money, gifts and other items to pass exams, and so on. Many students are not concern about studies, instead they are of the view that they can easily cough out some amount of money to upgrade their poor results with their exams officers.

Many lecturers who should be role models, have also contributed to high rate of corrupt academic practices in the university system. They ask students to submit assignments with monies; while those who did not meet such financial obligations are penalized. They set questions outside what was taught with the hope that students will not be able answer, giving room for the vast majority of them to sort for help, and pay monies in the process to pass. Some male lecturers sexually harass female students in order to pass them; while many examination officers have been reported to be demanding huge sums of monies from students to upgrade their results. Consequently, a student who ordinarily supposed to graduate with a third-class degree, now graduates with first class or second-class upper degree.

In an attempt to appear innocent, some lecturers make use of students, or in most cases, class representatives. These 'class reps' in themselves, are mostly made of people who are academically unserious, and as such, use their position to get good grades through the favour of some lecturers. Many class captains have been duping and defrauding their colleagues of huge sum of monies when they are assigned by corrupt lecturers to mobilize monies from other students. In some cases, many class captains add extra charges to whatever was demanded by the corrupt lecturer as fees to pass the course; while in other cases, they 
collect the actual sum demanded by the lecturer or even higher, without remitting same to the lecturer. As a result, the money doesn't get to the lecturer, while the students from whom such money was collected, ends up failing the course. Since this, in the first place is an illegal business, no serious action is taken.

Several measures have been used to reduce this menace of corrupt academic practices by lecturers and students especially in the University of Calabar, and Cross River University of Technology (CRUTECH). Quality assurance has been set up in these institutions to monitor teaching and examination malpractices on the part of lecturers and students respectively. Also, the university communities have been disciplining those caught in the act on strict grounds. Many other measures such as conference marking, submission of results after two weeks, banning the idea of class reps (who mobilize and defraud others), and so on, have been introduced to eliminate the chances of students passing examinations through their teachers corrupt illegal means. Despite all these and many more in place, many lecturers and students are still engaging in this dubious act. In the past, many lecturers claimed that they do some of these things to help students; so that they will not be regarded as wicked people. Some also blame the poor working conditions coupled with non-frequent payment of salaries as reasons responsible for this act. Many improvements have been made in recent times to improve teachers' welfare and their general working conditions. Given the persistent nature of corrupt academic practices by lecturers and students, not all lecturers nor students can be said to be corrupt. But why are some not corrupt? Since they all are in the same environment, with the same working conditions. It is on this note that the researchers wonder whether personnel management relates to corrupt practices in the universities.

Personnel management refers to the systematic process of providing services and ensuring that every person within the organization put in needed efforts, to the activities of the organization. Personnel management (PM) include such activities as recruitment, selection, training, placement, job analysis, discipline, supervision, promotion and remuneration (Owan, 2018).According to Shalik (2018), the objectives of staff personnel management include: to establish employee recruitment and selection systems for hiring the best possible employees consistent with the organisation's needs; to maximise the potential of each employee in order both to attain the organisation's goals and ensure individual career growth and personal dignity; to retain employees whose performance helps the organisation realise its goals and to release those whose performance is unsatisfactory; and to ensure organisational compliance with state and central government laws that is applicable to the personnel management function.

It can be said from the foregoing that the management of any organisational unit or department marketing, finance, accounting or production involves the accomplishment of 
objectives through the use of the skills and talents of people. Personnel management is considered both a line management responsibility and a staff function. In any type of organisation large, medium or small human resources must be recruited, compensated, developed, supervised, motivated and performance appraisal must be finalised and implemented by managers. The role of personnel management in an organisation's strategic management planning is of considerable importance. It helps organisations to find ways to compete effectively at home and internationally. Quality and productivity constitute the core of managing work, organisations, people and operations because they are critical to costs, competitiveness and profitability.

Several studies have been conducted in the area of corruption and its relationship to tertiary institutions. Kawugana and Woyopwa (2017), investigated the impact of exam malpractice on the quality of graduates in Nigeria. The research design used for the study was both quantitative and qualitative. The study area was the Federal Polytechnic, Bauchi State. Stratified sampling technique was used to select 400 sample sizes; while questionnaire and interview were used as instruments for data collection. The data collected were analysed using analysis of variance. The results of the analysis revealed that that there is high level of corruption in the educational sector due the large number of private schools instead of government to improve its own. The finding of the study also revealed that in Nigeria, certificates are valued more than the knowledge acquired which make some of the student to embark on exam malpractice to pass so that they will have the certificate. The finding of the study further revealed that there is no implementation of exam malpractice instead, it has been changed to exam misconduct due to high level of corruption.

Based on these findings, it was recommended among other things that teachers be trained properly in their fields. This will help them to develop the tactics in order to follow to finish the syllabus for a particular term or at least cover a large part of it; guidance counsellors should be employed in all schools to guide the students on their study habits, career prospects and requirement for various careers; the number of invigilators and supervisors should be increased in the exam halls. Exam officers, vice principals and principals should occasionally pay visits to exam halls to observe what is going on. In this way, they could notice any cheating behaviour; the students should be thoroughly searched before entering the hall. Apart from this, photographs, finger prints on certificates should be used for identification as no two persons; even identical twins could have the same finger print. That is why it is used in crime detection; over-emphasis on certificate and materialism to the detriment of knowledge and skill, need to be reversed (Kawugana \& Woyopwa, 2017). 
From the foregoing, it can be deduced that there exist a handful of studies conducted in the Area of corruption. The few existing studies were not conducted using corruption as dependent variable. There seem to be no study conducted in Cross River that examined staff personnel management and its relationship to corrupt practices in tertiary institutions in general, or universities specifically. This means that there are several gaps in the literature that must be filled. Therefore, this study is different from all other existing studies, and has been conducted to fill a gap by examining staff personnel management and corrupt academic practices in Cross River State, Nigeria.

\section{Statement of the problem}

Under an ideal situation, lecturers and students are supposed to display good moral attitudes, and work harmoniously in a manner that will lead to the realization of set goals. This was supposed to be done, free from all forms of corruption so that the graduates produced afterwards, can be employable, and contribute meaningfully to national development.

Unfortunately, many undergraduates in Cross River State do not take their studies seriously, they do not read their books, nor do they use the library, and are often found resorting to such things as copying, cheating and engaging in all forms of malpractices as means to pass an examination. Most students rarely attend classes, and do not take part in several assessments, with the mind-set that they could easily cough out some amount of money to some lecturers and obtain good grades. On the other hand, most lecturers who should be role models to students are not helping matters. Many lecturers are mercantile in nature, as they have been observed many times to be extorting monies and other resources from students in order to offer them grades they do not merit. These other resources include receiving gifts from students, making students pay for drinks, meat and other items during outing, paying with sex (in the case of a male lecturer and female students), recharge cards, appreciation, and so on. This is a clear indication why many students' out-of-school performances have dropped significantly causing an imbalance between quality of graduates produce and economic productivity as well as personnel efficiency on-the-job. This has implication for teacher education, education in general, and economic growth and development. How can a nation grow where majority of its populace are half-baked? This is also a reason why the universal basic education, secondary education, and tertiary education curriculum has failed in its implementation stages. Where are the teachers to impart scientific skills, vocational skills, technical skills, and even literacy and numeracy skills to our young children when the so-called future teachers cannot read and write? Old teachers are passing away and the future ones are supposed to fill their boots and even do better through technological innovations. Sadly, the 
university produces most graduates without the basic ability to read or write, and consequently, without the skills to be employed. This may have explained why many graduates are unemployed in Cross River State, or perhaps Nigeria.

The wide range of academic malpractice in the university system will hinder/limit the attainment of the objectives of Nigerian education, teacher education and the objectives of other education related policies and programme, unless something is done swiftly to cushion these misdemeanours in the university system. It is based on this that the researchers wonder whether improper staff personnel management could be related to this menace. An attempt to investigate this relationship, gave rise to the study.

\section{Purpose of the study}

The main purpose of this study was to investigate staff personnel management and corrupt academic practices in universities in Cross River State. This study sought specifically, to investigate:

i. The extent to which discipline and remuneration of lecturers influence corrupt academic practices in universities.

ii. The extent to which discipline and supervision of university students influence corrupt academic practices in universities.

\section{Research Questions}

The following research questions were posed to guide the study

i. To what extent does discipline and remuneration of lecturers influence corrupt academic practices in universities?

ii. To what extent does discipline and supervision of university students influence corrupt academic practices in universities?

\section{Statement of hypotheses}

The following null hypotheses were formulated to guide the study.

i. Discipline and remuneration of lecturers has no significant influence on corrupt academic practices in universities.

ii. Discipline and supervision of university students has no significant influence on corrupt academic practices in universities. 


\section{METHODOLOGY}

The research design adopted for the study was a factorial research design. This design was considered appropriate because factorial designs allow experiments to have more than one independent variable (factors), and either a dependent variable or dependent variables with categories (levels). The population of this study was all the lecturers and students of University of Calabar and Cross River University of Technology (CRUTECH). A purposive sampling technique was used to select sample of one thousand, four hundred (1400) respondents. Out of these, 600 were students from the University of Calabar, while 600 were students from CRUTECH; while 200 lecturers were randomly sampled from both universities with each having 100 lecturers respectively.

The instrument used for data collection was a 25-item rating scale that was designed to assess both students and lecturers respectively. The instruments were administered to the respondents by the researchers on different. The collected were analyzed using descriptive statistics. In testing the hypotheses at .05 alpha level, multiple regression analysis was used.

\section{ANALYSIS AND RESULTS}

\section{Research Question One}

To what extent does discipline and remuneration of lecturers influence corrupt academic practices in universities? For providing an answer to this question, the results presented in table 1 was used.

Table 1. Summary of multiple regression results showing the influence of discipline and remuneration of lecturers on corrupt academic practices in universities in Cross River State

\begin{tabular}{cccc}
\hline Multiple R & R Square & Standard Error & Observations \\
\hline .11103 & .01233 & 2.6399 & 1400 \\
\hline
\end{tabular}

The results presented in table one, indicates that discipline and remuneration of lecturers have a joint positive relationship to corrupt academic practices in universities. The relationship $(\mathrm{R}=$ .11103) was a weak positive relationship. However, discipline and remuneration contributed to 1.233 per cent $(\mathrm{R}$ square $=.01233$ ) of lecturers corrupt academic practices in the universities, with the remaining 98.767 per cent due to other factors not examined in the study.

\section{Hypothesis One $\left(\mathrm{Ho}_{1}\right)$}

Discipline and remuneration of lecturers have no significant influence on corrupt academic practices in universities. In order to determine whether the $\mathrm{R}$ value of .11103 obtained in table 1 
was statistically significant, ANOVA of the multiple regression analysis presented in table 2 was used.

Table 2. ANOVA of the regression analysis of the influence of discipline and remuneration of lecturers on corrupt academic practices in universities in Cross River State

\begin{tabular}{lccccc}
\hline Source of Variation & Df & SS & MS & F & Sig. F \\
\hline Regression & 2 & 121.517 & 60.759 & 8.71845 & .000173 \\
Residual & 1397 & 9735.657 & 6.969 & \\
Total & 1399 & 9857.174 & & \\
\hline \multicolumn{5}{c}{ * Significant at $\mathrm{P}<.05$}
\end{tabular}

The results presented in table reveal that the P-value .000173 is less than .05 level of significance. Thus, the null hypothesis was rejected implying that discipline and remuneration of lecturers have a significant influence on corrupt academic practices in universities in Cross River State. In determining the staff personnel factor with the highest influence on corrupt academic practice, the results in table three was used.

Table 3. Relative contribution of discipline and remuneration of lecturers to corrupt academic practices in universities in Cross River State

\begin{tabular}{lcccc}
\hline Variables & Coefficients & SE & t Stat & P-value \\
\hline Intercept & 6.317 & .2882 & 21.922 & $.0000^{*}$ \\
Discipline of lecturers & .02424 & .0344 & .7047 & .4811 \\
Remuneration of lecturers & .15431 & .0484 & 3.1875 & .0015 \\
\hline
\end{tabular}

The results presented in table one revealed that the P-value .0000 is less than .05 level of significance. This implies that, discipline and remuneration of lecturers, jointly have a significant influence on corrupt academic practices in universities.

However, remuneration of lecturers had the highest influence on corrupt academic practices in universities with $p$-value .0015 being less than .05 significance level and $t=3.1875$ being greater than .7047. Discipline of lecturers had an influence on corrupt academic practices in universities which was statistically insignificant with $p$-value .4811 being greater than .05 significance level. 


\section{Research Question Two}

To what extent does discipline and supervision of university students influence corrupt academic practices in universities? For answering this research question, the data presented in table 4 was used.

Table 4. Summary of multiple regression results showing the influence of discipline and supervision of university students on corrupt academic practices in universities in Cross River State

\begin{tabular}{cccc}
\hline Multiple R & R Square & Standard Error & Observations \\
\hline .0954 & .0091 & 2.6441 & 1400 \\
\hline
\end{tabular}

The results presented in table 4, revealed that the discipline and supervision of university students have a combined weak positive relationship to corrupt academic practices in the universities. The variance (.0091) indicates that out of all factors, discipline and supervision could be used to explain 0.91 per cent of university students' corrupt academic practices. However, 99.09 per cent of corrupt academic practices could be explained by other factors not studied.

\section{Hypothesis Two $\left(\mathrm{Ho}_{2}\right)$}

Discipline and supervision of university students has no significant relationship to corrupt academic practices in universities. The results of the analysis are presented in tables 5 , and 6 .

Table 5. ANOVA of the regression analysis of the influence of discipline and supervision of university students on corrupt academic practices in universities in Cross River State

\begin{tabular}{lccccc}
\hline Source of Variation & Df & SS & MS & F & Sig. F \\
\hline Regression & 2 & 89.830 & 44.915 & 6.4241 & .00167 \\
Residual & 1397 & 9767.344 & 6.992 & & \\
Total & 1399 & 9857.174 & & & \\
\hline
\end{tabular}

* Significant at $\mathrm{P}<.05$

The results presented in table 5 revealed that the p-value .00167 is less than .05 alpha level, as a result, the null hypothesis is rejected implying that discipline and supervision of university students has a significant relationship to corrupt academic practices in universities. In determining the factor that influenced students' corrupt academic practices most, the results presented in table 6 was used. 
Table 6. Relative contributions of discipline and supervision of lecturers on corrupt academic practices in universities in Cross River State

\begin{tabular}{lcccc}
\hline Variables & Coefficients & SE & t Stat & P-value \\
\hline Intercept & 7.9557 & .3743 & 21.251 & $.0000^{*}$ \\
Discipline of university students & .03883 & .0192 & 2.013 & .0443 \\
Supervision of university students & -.0746 & .0251 & -2.977 & .0030 \\
\hline
\end{tabular}

The results presented in table two indicates that the p-value $.0000^{*}$ is less than .05 level of significance. Therefore, discipline and supervision of students have a significant influence on corrupt academic practices in universities. The p-values .0443 and .0030 are less than .05 level of significance, indicating that both discipline and supervision had significant relationship to corrupt academic practices in universities respectively. However, supervision of university students had the most influence on corrupt academic practices in the universities.

\section{DISCUSSION OF RESULTS}

The findings of this study established that discipline and remuneration of lecturers jointly relate to corrupt academic practices in the universities. It was also revealed that discipline and remuneration of lecturers influenced lecturers' corrupt academic practices in the universities, with remuneration having the most influenced. These two factors jointly contributed to 1.23 per cent of lecturers corrupt academic practices in the universities, with the remaining $98.767 \mathrm{per}$ cent due to other factors not examined in the study. Also, staff remuneration was relatively significant in explaining lectures corrupt practices. Discipline alone was relatively insignificant in explaining lecturers' corrupt practices in the universities. The practical implication of this result is that when lecturers are adequately remunerated through timely and proper payment of salaries and wages, the rate of corrupt academic practices such as extortion, sorting, asking for gifts and so on will decrease. This is true because in most cases, lecturers are not promptly paid. In situations where they are even paid, only part salaries are paid which is enough to cater for their basic and other family needs. Disciplinary management techniques are already in place in most universities, like in University of Calabar and CRUTECH respectively, much improvement has been made to discipline lecturers caught engaging in corrupt academic practices. This perhaps the reason why discipline alone was statistically insignificant in predicting lecturer' corrupt practices.

The result of this study have a link to the position held by Nwaokugha and Ezeugwu (2017), who reported that classroom teachers are not left out in the orgy of corruption and corrupt practices in Nigeria's education industry, and a pattern of corruption that is unique to 
them is sale of grades, sexual harassment, absenteeism, fragrant abandonment of teaching and in its place, engineering and initiating a culture of private practices, whereby learners are forced to participate in such privately organized tutorials using school facilities.. Following Nwaokugha and Ezeugwu explanations, what will you expect from someone who work without payment and without any other source of income? The person will resort into various activities as means to an end. Hence lecturers are engaging in corruption due to failure on the part of the Government.

The findings of this study also revealed that discipline and supervision of university students have a joint positive relationship to their corrupt academic practices. These two factors also had a significant influence on university students' corrupt academic practices. Discipline and supervision contributed 0.91 per cent influence on university students' corrupt academic practices, with the remaining 99.09 per cent of university students corrupt academic practices emanating from other factors not included in the study. Out of the two factors, both were relatively influential in explaining students' corrupt academic practices, with students' supervision having the most influence on corrupt academic practices.

The implication of this finding is that students are not properly supervised during academic and non-academic activities by the school regulatory bodies. Students need to be adequately supervised and monitored during examinations, after examinations, in school and even in the hostel. When students are not adequately supervised, they cannot be properly disciplined. The reason is that you cannot discipline someone you do not know. It is through proper supervision that corrupt students are caught, before disciplinary actions can be taken against them. It can be added that the high rate of corruption on the part of students is due to the fact that majority of the students often go unnoticed. This finding supports the recommendations of Kawugana \& Woyopwa (2017), that exam officers, vice principals and principals should occasionally pay visits to exam halls to observe what is going on. In this way, they could notice any cheating behaviour; the students should be thoroughly searched before entering the hall. Apart from this, photographs, finger prints on certificates should be used for identification as no two persons; even identical twins could have the same finger print. That is why it is used in crime detection; over-emphasis on certificate and materialism to the detriment of knowledge and skill, need to be reversed.

\section{CONCLUSION}

Based on the findings of the study, it was concluded that lecturers' remuneration contributed significantly to corrupt academic practices in the universities; discipline of lecturers had no significant contribution to lecturers' corrupt academic practices. It was also concluded that discipline and remuneration of lecturers jointly influenced lecturers' corrupt academic practices 
in school. It was also concluded that discipline and supervision have an influence on corrupt academic practices respectively. Supervision of students had the most influence on corrupt academic practices in universities.

\section{RECOMMENDATIONS}

Based on the findings of the study, it was recommended that:

i. Lecturers should be properly remunerated through frequent payment of salaries, and other wages in order to ensure that they do not lack food and other resources to manage and take proper care of their families.

ii. Lecturers caught engaging in corrupt academic practices should be apprehended, and disciplined in order to prevent such unwanted attitudes from re-occurring in the future, and to serve as a deterrent to others.

iii. Students should be supervised properly during examinations and in other academic/ cocurricular activities of the universities. Those caught exhibiting corrupt academic practices should be suspended or withdrawn from the university system, to prevent them from passing such bad attitudes to other students especially new students.

iv. There should be urgent institution of conference marking policy, as well as swapping of examination scripts to other competent lecturers within the same department or unit for marking. When these are in place, both lecturers and students become unaware of where their exams are being marked, and will reduce the rate of examination malpractice.

\section{LIMITATIONS OF THE STUDY}

The findings of the study were limited first by the fact that, the study did not cover all the variables of personnel management. Only four variables of independent variable were covered. Consequently, the variables not covered in the study are extraneous and could pose a serious threat to the findings of the study.

The study was also limited to only two tertiary institutions in one state in Nigeria. The implication is that the results so obtained may be different had the study been conducted on a larger scope. Consequently, the findings of this study could be generalized based on the scope covered. 


\section{REFERENCES}

Brunelle - Quraishi, O (2011). Assessing the Relevance and Efficiency of the United Nations Convention Against Corruption: A Comparative Analysis. International Notre Dame Journal of International \& Comparative Law; 5(4): 10 166.

Heyneman, S. P. (2003). Education and misconduct. In James G. (eds.) Encyclopaedia of Education. New York: Macmillan Publishers.

Heyneman, S. P. (2009). Buying your way into heaven. Education and corruption in international perspective. Rotterdam/Taipei: Sense Publishers,

Kawugana, A. \&Woyopwa, A. K. (2017). Impact of exam malpractice on the quality of graduates in Nigeria. International Journal of Education and Evaluation; 3(6): $45-51$.

Lawal, G and Tobi, A (2006). Bureaucratic corruption, good governance and development: The challenges and prospects of institution building in Nigeria. International Journal of Applied Sciences Research 2(10): $642-649$.

Nwaokugha, D. O. \& Ezeugwu, M. C. (2017). Corruption in the education industry in Nigeria: implications for national development. European Journal of Training and Development Studies; 4(1): 1 - 17.

Ojiade, F. (2000) The professional accountant and anti-corruption crusade. In ICAN News July/September.

Owan, V. J. (2018). Administration of personnel management functions: implication for the school. Retrieved from https://goo.gl/KUQiiq on 8th July, 2018.

Shalik, M. (2018). Personnel Management: Meaning, Objectives and Importance. Retrieved from https://goo.gl/q1fhkj 